\title{
Study on the Model of Participation of Students with Major of Art Design in Design Practice Projects of Enterprises
}

\author{
Wei Zhang \\ The Department of art and design, Teachers' College \\ Beijing Union University \\ Beijing, China \\ sftzhangwei@buu.edu.cn
}

\begin{abstract}
Participation in design practice projects of relevant enterprises is not only the demand for effectively implementing practical teaching of art design major, but also the requirement of enterprises on applied professional talents. Cultivation of talents with major of art design or professional talents is not only the problem facing education decisionmarker of colleges and universities, but more importantly, the responsibility of professional teachers staying ahead of teaching and closely related to cultivation of professional talents. Only by exploring the effective model for students to take part in design practice projects of enterprises can students truly participate in design practice projects of enterprises so as to improve professional practice ability rapidly and make full preparation for successful employment.
\end{abstract}

\section{Keywords- art design; enterprise; design practice project}

\section{INTRODUCTION}

Contradiction of employment difficulty of graduates and "Unavailability of talents" of enterprises acts as a reminder for colleges and universities to think the way of adjusting talent cultivation scheme for meeting the demands of enterprises on professional talents. Cultivation scheme of talents with major of art design should also be prepared based on enterprise demands. In order to transfer professional knowledge of students into design practical ability required by enterprises, efforts should be made to explore the effective model vigorously for students' participation in design practice of enterprises with a view to improving design practical ability of students with major of art design continuously, meeting the requirements of enterprises and adapting to duty post as soon as possible.

1. 2011 topic of "Twelfth five-year plan" for education and science in Beijing: study on the model of participation of students with major of art design in design practice projects of enterprises (Topic No.: DEB11100). 2. Topic of "Twelfth five-year plan" higher education and scientific research planning of Beijing Association of Higher Education: study on talents cultivation model for participation of students with major of art design in design projects of enterprises (Topic No.: BG125YB024).

3. Education and teaching research and reform project of Beijing Union University: study on talent cultivation of art design major in the application-oriented university.

4. Project of funding backbone teachers in Beijing Union Teacher based on the talents developing strategy: study on practical teaching model of art design oriented by design projects of enterprises.

\author{
Jiang Li \\ The Department of art and design, Teachers' College \\ Beijing Union University \\ Beijing, China \\ sftlijiang@buu.edu.cn
}

\section{PROBlEMS EXISTING IN THE PARTICIPATION OF STUDENTS WITH MAJOR OF ART DESIGN IN DESIGN PROJECTS OF ENTERPRISES}

As an important part of practical teaching system of colleges and universities, off-campus talent cultivation base plays an important role during the process of cultivating students' professional practical ability and the effective method or means to cultivate practical ability and teamwork spirit of students of colleges and universities is to participate in internship in the off-campus talent cultivation base of cooperative enterprises. Currently, many colleges and universities always assign students to take part in internship in enterprises during some certain period and this practical teaching model is applicable to majors within certain extent; however, it is always difficult to implement the practical teaching for students with major of art design; it should be known that period for enterprise to have design projects is uncertain. If the time for students with major of art design to take part in internship in enterprises is fixed, students may have to be engaged in simple service work and fail to realize the purpose of improving the professional design practical capability due to lack of design projects in enterprises; in addition, due to increased enrollment of students with major of art design in recent years, number of students with major of art design in the standard teaching class has been increased gradually and it is difficult for enterprises to receive students of one standard teaching class to participate in internship in enterprises during the same period at the same time, which may cause certain difficulties for practical teaching of art design major. Therefore, during the process of deepening the reform of practical teaching system of art design major, flexible and effective model should be applied to make students participate in design projects of enterprises truly and put the practical teaching of art design major into practice by guaranteeing normal teaching order and preparing practical teaching plan based on operation rules of design projects of cooperative enterprises so as to cultivate professional talents with major of art design adapting to enterprise demands and possessing strong practical ability, which is the significance for exploring the effective model for students with major of art design to take part in design practice projects of enterprises. 


\section{EXPLORATION OF PARTICIPATION MODEL OF STUDENTS IN DESIGN PROJECTS OF ENTERPRISES}

\section{A. Match Design Practice Projects of Enterprises with Teaching Plan}

Although time for enterprises to have design projects is uncertain, it still has rules to follow. It is possible to determine design projects suitable for students by studying operation rules of design projects of enterprises and obtain better internship effects by matching operation period of these projects with practical teaching plan. Take the preparation of practical teaching plan of Art Design Department of Teacher's College of Beijing Union University for instance. Beijing Gehua Cultural Creative Industry Center is the off-campus talent cultivation base of Teacher's College of Beijing Union University. As design projects of Beijing Gehua Cultural Creative Industry Center are mostly related to major of art design, Art Design Department of Teacher's College of Beijing Union University often arranges students to take part in internship in this center. After study on design projects of Beijing Gehua Cultural Creative Industry Center, design projects of this center are divided into design projects of fixed period and design projects of non-fixed period. Design projects of fixed period refer to those projects conducted by this center every year: project of design and promotion for "Beijing International Film Festival" at the end of April, project of exhibition arrangement for "Beijing International Design Week" from the end of September to the beginning of October or project of exhibition arrangement for "International Cultural Creative Industry Expo" at the middle ten days of November every year; design projects of nonfixed period refer to those external design projects undertaken by this center irregularly, such as exhibition of $90^{\text {th }}$ anniversary of party building, art exhibition of Italian Renaissance and so on. After investigation and surveying of operation rules of design projects of Beijing Rose Studio Haute Couture, another cooperative enterprise of Teacher's College of Beijing Union University, it can be found that this costume design company mainly orders stage performance costume and operation period of its design projects is mainly from October to spring festival. Moreover, operation rules of design projects of these enterprises can also be found out by researching and investigating other off-campus talent cultivation bases. Therefore, practical teaching plan of art design major of teachers college should be centered on operation rules of design projects of these cooperative enterprises, match operation period of design practice projects of these enterprises with teaching plan of art design major according to teaching law of art design major, arrange students to take part in internship at the period during which enterprises have relatively intensive design projects and guarantee students' participation in projects truly during the course of internship so as to improve the comprehensive capacity of students to deal with design project and realize the purpose of taking part in design practice of enterprises during design practice process.
B. Adopt Flexible and Multiple Forms to Participate in Design Practice Projects of Enterprises

1) Adopt the participation model with teaching class being unit for design projects of fixed period.

Design practice projects of enterprises are generally divided into design projects of fixed period and non-fixed period. Colleges and universities are willing to take part in activities of design projects of fixed period in that such projects have certain laws and principles and normal teaching order of colleges and universities can be guaranteed through reasonable arrangement. Incorporating design projects of fixed period of enterprises into practical teaching plan of art design major and participating in design projects in the form of standard teaching class based on actual circumstances can consolidate the professional practice ability of students targetedly and make students know about future working environment. Design projects of fixed period are applicable to freshmen and sophomores with intensive courses.

2) Adopt the participation model with design team being unit for design projects of non-fixed period

Besides design projects of fixed period, design projects of enterprises are mostly projects of non-fixed period, namely operation period of design projects is not controlled by enterprises themselves and there are no rules to follow. It is difficult to match such design projects with teaching plan of art design major and inappropriate for participation in the form of standard teaching class. However, as vast majority of design projects of enterprises are projects of non-fixed period, it is required to take proper measures to guarantee students' participation in it. After cooperation with enterprises for many times, it is determined to take part in design projects of non-fixed period in the model of design team. Standard teaching class with 25 students is divided into 5 design teams and such teams are combined by the means of complementing each other's advantages with a view to matching coursework of students with major of art design with design projects of non-fixed period of enterprise as far as possible. During the course phase, 5 design teams of teaching class will take part in this design project. During the design process, 1 design team will be selected according to evaluation of instructors and responsible people of design projects of enterprises at the end of course to follow up this project continuously for the purpose of guaranteeing successful implementation of design project. Moreover, during the follow-up process, design progress of remaining 4 teams should be reported in the form of summary.

It is required to take part in non-fixed design practice project of enterprises selectively and arrange students of relevant majors to take part in such projects according to teaching plan of colleges and universities under the premise of not affecting teaching order of colleges and universities. Of course, when one design team is selected to follow up design project, this design team should be given certain preferential policies based on actual circumstances for ensuring that implementation of design project of enterprises will not be delayed, guaranteeing the smooth operation of design project and maintaining good 
collaborative relationship between enterprises and colleges and universities. After project completion, leading teacher and responsible people of project should evaluate and appraise the work performance of students for inspecting the application of design practice capability of students. Moreover, design team following up the project should make report for further perfecting participation model of non-fixed design practice projects. This participation model of design projects of enterprises with design team being unit is applicable to sophomores and juniors.

3) Adopt the model of project team from different grades to participate in design practice projects of enterprises.

In order to build talent cultivation system integrating industry-university-research cooperation into a whole, Teacher's College of Beijing Union University has created on-campus students' practice platforms, such as creative practice center and art design institute, and made full use of such on-campus practice platforms, which may also contribute to improving the design practice capability of students with major of art design. On-campus students' practice platform adopts workroom system. For instance, creative practice center consists of animation design workroom, old movie restoration workroom and movie and television website maintenance workroom; art design institute consists of costume design workroom, environment design workroom and visual communication design workroom. Workroom members mainly consist of regular teachers of colleges and universities and these workrooms undertake design practice projects of the government, public institutions and enterprises by depending on resources of colleges and universities. During the operation process of projects, teacher in charge of project of each workroom should form a project team by selecting students from different grades and majors according to project design contents. These design projects will be completed by project team of different grades led by teacher and will not occupy school time of students as students come to workroom to work with teacher after class. After project completion, project team of different grades will be dissolved. When it is required to conduct another design projects, leading teacher will re-form project team from different grades.

The advantages of participating in design practice projects in the form of project team from different grades are as follows: students can consolidate the professional design capability by using spare time. Students from different majors and grades may broaden horizon and enhance design communication capability through mutual exchange; of course, students will be given proper service charge according to its efforts, which may help students experience a sense of accomplishment brought by professional knowledge. This project team of different grades is generally applicable to sophomores, juniors and seniors. Team members are mainly juniors and seniors because juniors and seniors have more spare time and possess certain professional design knowledge.

\section{IMPLEMENTATION GUARANTEE FOR STUDENTS' PARTICIPATION IN DESIGN PRACTICE PROJECTS OF ENTERPRISES}

Implementation of students' participation in design practice projects of enterprises is closely related to good cooperative relationship between colleges and universities and enterprises, perfect practical teaching management system and design guidance team with clear labor division.

\section{A. Establish the Long-Term Mechanism of Mutual Beneficial Cooperation Between Colleges and Universities and Enterprises}

Maintaining good cooperative relationship between colleges and universities and enterprises is the premise for guaranteeing students' participation in design practice projects of enterprises. Off-campus practical teaching base provided to colleges and universities by enterprises is beneficial for consolidating professional practice ability of students. During this process, efforts should be made to give full play to professional skills of students to make enterprises earn benefits, rather than using enterprises as educational institution purely. If students fail to play a part in the operation process of design practice project of enterprises or even affect the operation of design projects of enterprises, such cooperation will not last long. From the perspective of experience of cooperation between Beijing Union University and Beijing Gehua Cultural Creative Industry Center, Beijing Gehua Cultural Creative Industry Center provides students with design practice projects and selects senior designers to give lessons to students; at the same time, Beijing Union University provides technical support and design volunteers for design projects of fixed period held by Beijing Gehua Cultural Creative Industry Center every year and delivers professional talents with major of art design to enterprises stably. A long-term mechanism is established on the basis of mutual benefits for maintaining the cooperation relationship between colleges and universities and enterprises substantially.

\section{B. Perfect Management System of Practical Teaching}

Perfect management system of practical teaching is also the important guarantee for students to enter enterprises successfully and take part in design practice projects. Firstly, prepare practical teaching plan based on operation rules of design projects of enterprises and select design practice projects properly so as to make students have design tasks during the internship in enterprises; secondly, when students are led to take part in design practice of enterprises, agreements should be signed after the consultation between colleges and universities and enterprises for defining the responsibilities of each party; thirdly, purchase personal insurance for students and entrust leading teacher and internal personnel of enterprises to manage students jointly for guaranteeing the personal and property safety of students; in addition, establish the system of evaluation by colleges and universities and enterprises for stimulating and promoting the students' performance during the design practice process, creating good reputation inside enterprises 
and in society for colleges and universities and further guaranteeing the stability of platform of cooperation between colleges and universities and enterprises.

\section{Design Guidance Team with Clear Labor Division}

When students participate in design practice process of enterprises, there may exist a process of role transition, which means that students will become designers needing to solve problems proactively, rather than passive recipients of knowledge. This process requires experienced designers to help students digest and apply professional knowledge accumulated to design practice. Therefore, when students participate in design practice of enterprises, teachers with rich design experiences should form design guidance team with clear labor division to help students solve technical and ideological problems, facilitate role transition of students and complete design tasks assigned by enterprises successfully.

\section{CONCLUSION}

Practical teaching should not only rest on visits of enterprise location and understanding of operation process of design projects. Flexible and proper model should be used to make students participate in design practice projects of enterprise truly, which is not only the demand of implementing practical teaching of art design major, but also the demand of enterprises for applied professional talents.
Cultivation of talents with major of art design and professional talents is not only the problem facing education decision-marker of colleges and universities, but more importantly, the responsibility of professional teachers staying ahead of teaching and closely related to cultivation of professional talents. Only by exploring the effective model for students to take part in design practice projects of enterprises can students with major of art design truly participate in design practice projects of enterprises so as to improve professional practice ability rapidly and make full preparation for successful employment.

\section{REFERENCES}

[1] Liu Yuli. " Thinking on the Teaching Practice Course of Environmental Art Design Major [J]" . Education thinking, 2003(4): 36.

[2] Zhang Baoxiu. "Scientific Research of Application-oriented University $[\mathrm{J}]$ " . Journal of Beijing Union University: special issue of education and teaching research, 2006(20): 10-13.

[3] Zhangqi. "Innovation of Vocational Ability Cultivation and Art Design Teaching [M]. Study on Theory and Practice Development of Contemporary Vocational Education" , Harbin: Publishing House of Northeast Forestry University, 2008: 167.

[4] Xie Chongqiao. "Real and Virtual Topic in the Practical Teaching of Art Design Major [M]. Exploration and Practice of Applied Talents Cultivation" , Beijing: Intellectual Property Publishing House, 2009: 58. 